Pamiętnik Literacki 2020, 3, s. 179-192

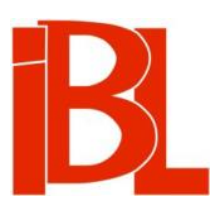

\title{
Źródla ze zbiorów Biblioteki Kórnickiej do historii Makryny Mieczysławskiej
}

Aleksandra Sikorska-Krystek, Jędrzej Krystek 
Pamiętnik Literacki CXI, 2020, z. 3, PL ISSN 0031-0514

DOI: $10.18318 / \mathrm{pl} .2020 .3 .11$

ALEKSANDRA SIKORSKA-KRYSTEK Uniwersytet im. Adama Mickiewicza, Poznań JĘDRZEJ KRYSTEK Uniwersytet im. Adama Mickiewicza, Poznań

\section{ŹRÓDŁA ZE ZBIORÓW BIBLIOTEKI KÓRNICKIEJ DO HISTORII MAKRYNY MIECZYSŁAWSKIEJ}

\section{1}

Historia rzekomo prześladowanej ksieni bazylianek mińskich, Makryny Mieczysławskiej, choć zbadana gruntownie przez ks. Jana Urbana, autora studium Makryna Mieczysławska $w$ świetle prawdy, wydanego w 1923 roku, a także pomniejszych artykułów opublikowanych na łamach „Przeglądu Powszechnego”, w których krakowski jezuita rozwijał podjęte przed laty dociekania ${ }^{1}$, skrywa wciąż sporo niejasności. Kapłan, któremu przyświecała myśl, aby „Nie [...] okrywać fałszu płaszczykiem pobożności”, był świadomy przełomowego charakteru swojej pracy. Jezuita zdawał sobie doskonale sprawę $z$,owianych urokiem poezji i nimbem świętości otoczonych przekonań [...]" dotyczących Mieczysławskiej ${ }^{2}$. Mimo iż prawdziwość opowiadania domniemanej mińskiej mniszki o 7-letnim prześladowaniu za wiarę z rąk biskupa-apostaty Józefa Siemaszki budziła wątpliwości jeszcze za życia bohaterki, konsekwentnie utrwalano jej historię po śmierci bazylianki, która nastąpiła w lutym 1869. Aż do opublikowania monografii ks. Urbana relacja zakonnicy ukazała się kilkakrotnie pod zmienionym tytułem - jako Pamiętniki Makryny Mieczysławskiej, ksieni bazylianek $w$ Minsk $u^{3}$. Budowaniu mitu męczennicy romantycznej sprzyjały również pomniejsze opracowania, jak np. artykuły na łamach poznańskiego „Przewodnika Katolickiego” ${ }^{4}$ czy też prace poświęcone historii unii

1 J. U r b a n: Makryna Mieczysławska w świetle prawdy. Kraków 1923; Notka w dziale Rozmaitości. „Przegląd Powszechny” 1923, t. 158; Recenzja dramatu Antoniego Waśkowskiego. Jw., 1930, t. 185; Pokłosie po pracy o Mieczysławskiej. Jw., 1934, t. 202, nr 605.

2 U rban, Makryna Mieczysławska $w$ świetle prawdy, s. 6.

3 M. Mieczysław ska: Pamiętniki Makryny Mieczysławskiej, ksieni bazylianek w Mińsku. Wyd. I. D a n i ele w s k i. Toruń 1878; Pamiętniki Makryny Mieczysławskiej, ksieni bazylianek w Mińsku. Nakładem wyd. im. ks. F. Bażyńskiego (W. Simona). Poznań 1880; Pamiętniki Makryny Mieczysławskiej, ksieni bazylianek w Mińsku. Drukiem i nakładem W. Dyniewicza. Chicago, Ill., 1886.

4 Zob. np. Z. K.: Życie za wiarę! Z krwawych dziejów naszych braci unitów. „Przewodnik Katolicki” 1911, nr 21; Z dziejów męczeństwa. Matka Makryna Mieczysławska. Jw., 1916, nr 8. Warto także wspomnieć artykuł S. Pig on ia List Makryny Mieczysławskiej („Pamiętnik Literacki” R. 17/18, 1920, s. 152), w którym badacz przywoławszy treść korespondencji zakonnicy do W. Wielogłowskiego, stwierdził, iż jest „list ten autentycznym świadectwem owego mistycyzmu Makryny, o którym świadczył Krasiński [...]". 
brzeskiej autorstwa ks. Edwarda Likowskiego ${ }^{5}$. Trudno także nie wspomnieć o obecności Mieczysławskiej na kartach dzieł literackich - wydanego po raz pierwszy pośmiertnie w roku 1861 poematu Rozmowa z Matka Makryna Mieczysławska Juliusza Słowackiego i młodopolskiego dramatu Legion Stanisława Wyspiańskiego.

Demaskacja mitologii Mieczysławskiej przez ks. Urbana była możliwa dzięki skonfrontowaniu treści wydrukowanego w 1846 roku w Paryżu Opowiadania Makryny Mieczysławskiej ${ }^{6} \mathrm{z}$ dokumentami dotyczącymi okoliczności prześladowania zakonu bazylianek na ziemiach polskich zaboru rosyjskiego, będącego efektem zniesienia postanowień unii brzeskiej. Autor poprzedził zestawienie przekazu fałszywej zakonnicy ze źródłami historycznymi relacją na temat m.in. pobytu bohaterki nad Sekwaną i przebiegu peregrynacji ksieni z Paryża do Rzymu w towarzystwie ks. Aleksandra Jełowickiego. Umożliwiło to ks. Urbanowi odnalezienie materiałów prasowych, ze szczególnym uwzględnieniem publikacji na łamach prasy emigracyjnej („Trzeci Maj”, „Dziennik Narodowy”), jak i francuskojęzycznej (m.in. „L’Ami de la religion et du Roi”, „L’Univers”). Przytaczając treść artykułów drukowanych jesienią 1845, jezuita wykazał, iż niezwykła historia rozrastała się sukcesywnie o nowe detale dotyczące prześladowania, aż do publikacji wspomnianego Opowiadania Makryny Mieczysławskiej, rzekomo spisanego między 6 XI a 6 XII 1845, w towarzystwie księży Aleksandra Jełowickiego, Maksymiliana Ryłły oraz Alojzego Leitnera. Co ciekawe, autorzy artykułu Les Religieuses basiliennes de Minsk, zamieszczonego w „L'Ami de la religion et du Roi” 16 X 1845, spostrzegli, że szczegółów o persekucjach wraz z upływem czasu wciąż przybywa, ale nie skłaniało ich to do podejrzeń w kwestii autentyczności relacji - wiadomości o nowych (nierzadko sprzecznych) okolicznościach prześladowań podawali bez komentarza ${ }^{7}$.

Ksiądz Urban nie omieszkał wspomnieć o pierwszych zeznaniach, które Mieczysławska miała złożyć 14 VIII 1845 podczas pobytu w Poznaniu, jednakże informacje, które przedstawiał w swej książce na ich temat, pochodziły z drugiej ręki. Pisał:

„L'Univers” donosi 30 września 1845 r. między innymi szczegółami i to, że już w Poznaniu spisano zeznania Mieczysławskiej dla przesłania ich Ojcu Świętemu. [...] Protokół poznański miał nosić datę sierpnia $1845^{8}$.

Dokument ten został odnaleziony kilka lat później i opublikowany przez Edmunda Majkowskiego w artykule Listy Matki Makryny oraz w samodzielnej broszurze, wydanej jako Przyczynki do życia i sprawy Makryny Mieczysławskiej ${ }^{9}$. Pisma te opierają się na materiałach odkrytych podczas prac zmierzających do utworzenia Archiwum Archidiecezjalnego w Poznaniu rozpoczętych staraniem biskupa Stani-

E. Li kow s ki, Dzieje Kościoła unickiego na Litwie i Rusi w XVIII i XIX wieku uważane głównie ze względu na przyczyny jego upadku. Wyd. 2. Cz. 2. Warszawa 1906, s. 118-119.

$6 \quad$ Opowiadanie Makryny Mieczysławskiej, ksieni bazylianek mińskich o ich siedmioletnim prześladowaniu za wiarę. Spisane przez M. Ryłłę, A. Jełowieckiego, A. Leitnera. Paryż 1846. Dalej do pozycji tej odsyłamy skrótem O. Liczby po skrócie oznaczają stronice.

7 Les Religieuses basiliennes de Minsk. „L'Ami de la religion et du Roi” 1845, nr 4129, z 16 X.

8 U rban, Makryna Mieczysławska $w$ świetle prawdy, s. 18.

9 E. Majkowski: Listy Matki Makryny. „Kurier Poznański” 1927, nr 201; Przyczynki do życia i sprawy M. Mieczystawskiej (z akt poznańskiego Archiwum Archidiecezjalnego). T. 3, nr 1/2. Lwów 1929. 
sława Łukomskiego, co urzeczywistniło się w październiku 1925. Stanowisko pierwszego dyrektora nowo powstałej placówki objął ks. Majkowski i funkcje tę sprawował do 1933 roku. Późniejszy proboszcz parafii pw. Wszystkich Świętych w Kórniku odnalazł listy Mieczysławskiej skierowane do ks. Mieczysława Ledóchowskiego. Zachęcony tym odkryciem postanowił szukać dalej i dotarł do dokumentów: protokołu spisanego przez księży Albina Thinela i Ludwika Urbanowicza 14 VIII 1845 w Poznaniu, korespondencji arcybiskupa Leona Przyłuskiego z biskupem chełmińskim oraz warmińskim (ks. Anastazym Sedlagiem i ks. Józefem Geritzem), a także listów Przyłuskiego do nuncjatorów apostolskich w Monachium i Wiedniu. O ile obecność ks. Thinela w trakcie sporządzania zeznań można łatwo wytłumaczyć - był on spowiednikiem Sióstr Miłosierdzia w Poznaniu, gdzie Mieczysławska najprawdopodobniej przebywała, o tyle obecność ks. Urbanowicza (ówczesnego proboszcza parafii św. Wojciecha) jest dużo bardziej frapująca. $Z$ artykułu Majkowskiego zamieszczonego w „Kurierze Poznańskim” wynika, iż Urbanowicz na polecenie arcybiskupa Przyłuskiego odpowiadał za spisywanie zeznań. Majkowski również zaznaczył, iż dokument ten nie był znany ks. Urbanowi. Co więcej, ks. Majkowski w Przyczynkach do życia i sprawy M. Mieczysławskiej opublikował odnalezione przez Józefa Grycza - dyrektora Biblioteki Kórnickiej, pochodzące ze zbiorów tej instytucji „uwierzytelnione świadectwa lekarskie przez Dyrekcję Policji” z datą 24 I 1849, jak i „,swiadectwo lekarskie dla Makryny Mieczysławskiej, stwierdzające, jakie urazy cielesne wykazało badanie w 1845 roku" z data 19 I 1849. Świadectwo lekarskie było zatem wydane niemalże po 4 latach od pobytu Mieczysławskiej w Poznaniu przez dwóch lekarzy: Wiktoryna Kramarkiewicza i Józefa Antoniego Jagielskiego. Ponadto jednym $z$ dokumentów opublikowanych przez Majkowskiego jest uwierzytelnienie obdukcji lekarskiej - rzekomej Makryny Mieczysławskiej, wystawione 3 II $1849^{10}$.

Dodać tu jeszcze należy, iż udostępnione przez Majkowskiego materiały nim zostały włączone do zbiorów Muzeum Archidiecezjalnego w Poznaniu, znajdowały się w majątku Mycielskich w Kobylempolu. Były tam ukryte przez arcybiskupa gnieźnieńsko-poznańskiego Leona Przyłuskiego, a po jego śmierci (w 1865 roku) umieszczone w fascykule opatrzonym quasi-tytułem Pisma sekretne po śp. Arcybiskupie Przyłuskim.

Materiały przedstawione przed laty przez ks. Urbana można uzupełnić dokumentami zgromadzonymi w Bibliotece Kórnickiej Polskiej Akademii Nauk. W teczce zatytułowanej Różne kościelne i religijne (sygn. BK 02683), zawierającej „oryginalne dokumenty i kopie", datowane na XVII-XX wiek, znajduje się manuskrypt oznaczony w katalogu archiwalnym jako Opowiadanie Makryny Mieczysławskiej 1845. Tekst nie nosi śladów ingerencji w treść. Wiadomo, iż rękopis został włączony do zbiorów biblioteki przed śmiercią Władysława Zamoyskiego w 1924 roku. Nie da się ustalić dokładnej daty pozyskania dokumentu. Można przyjąć hipotezę, że

10 W dokumencie tym nie odnajdujemy wszakże informacji o żadnych konkretnych rodzajach obrażeń, ich umiejscowienia czy też prawdopodobnych sposobów ich zadania. Przyłuski potwierdza w nim jednak z cała stanowczością, iż lekarze Kramarkiewicz oraz Jagielski orzekli to samo podczas pobytu Mieczysławskiej w Wielkopolsce w sierpniu 1845 (zastanawia, dlaczego wystawiono po latach tego typu dokument). 
znajduje się on w Bibliotece Kórnickiej od jego powstania, tj. od 1845 roku. Uważna lektura treści autografu ujawnia wszakże jego niekompletność. Tekst w fabule ma wyrwę, która obejmuje najprawdopodobniej jedną kartę. Manuskrypt musiał być niepełny przed nadaniem paginacji w obrębie zespołu. Rękopisu nie znał zarówno ks. Urban (którego wątek poznański prawie nie zajmował), jak i kontynuator jego dociekań, ks. Majkowski. Podajemy tu treść rękopisu w całości.

Autograf znajduje się na dwóch kartach in folio o wymiarach $23,7 \mathrm{~cm} \times 20 \mathrm{~cm}$, na stronicach 160-163, w ramach paginacji ciąłłej w obrębie zespołu. Cały napisany został jednakowym atramentem, równym i czytelnym pismem. Brzegi kart są zniszczone w stopniu, który nie narusza jego treści. Ortografię oraz interpunkcję zmodernizowaliśmy według obecnie obowiązujących zasad. Miejsca nieczytelne oznaczyliśmy trzema kreskami w nawiasie kwadratowym [---].

\section{PRZEŚLADOWANIE ZAKONNIC BAZYLIANEK KLASZTORU MIŃSKIEGO, GÓRY Ś. TRÓJCY (TROJECKIEJ)}

OPOWIADANIE JULII W ZAKONIE MAKRYNY MIECZYS ŁAWS KIE J PRZEŁOŻONEJ TEGOŻ KLASZTORU, PRZESZLO 60 LAT WIEKU MAJĄCEJ, ZAKONNEGO ZAŚ ŻYCIA ROK 36TY LICZACEJ W ROKU 1845

Roku 1836 wyszło w Rosji postanowienie cesarskie, nakłaniające w guberniach zachodnich mieszkańców unickiego wyznania do greckiej, błahoczestliwej ${ }^{11}$ cerkwi. W skutek czego naczelnik duchowieństwa unickiego, biskup Siemaszko, pierwszy odstapił od swego kościoła i udawszy się do Petersburga, w nadwornej cerkwi cesarskiej wykonał przystapienie do wiary greckiej z tytułem arcychireja ${ }^{12}$ czy arcybiskupa. Dokonawszy ten obrzęd, podał projekt do nawrócenia wszystkich unitów gwałtownymi środkami i otrzymawszy stosowne instrukcje, wrócił do stolicy swojej w Mińsku.

W mieście tym znajdował się klasztor panien bazylianek, z 35 zakonnic złożony, przeciwko nim więc Siemaszko obrócił swoje zamachy. Pokazał im podpis ręki cesarskiej udzielającej mu nieograniczona władzę do zniewolenia zakonnic wszelkimi sposobami, ażeby odstapiły Katolickiego Kościoła i przeszły do schizmy. Działo się to r. 1837, odkąd się rozpoczęły następne długoletnie prześladowania i cierpienia tego zakonu. Kilkakroć ponawiał Siemaszko wezwania swoje do bazylianek mińskich bądź na piśmie, bądź osobiście; dał im nareszcie pięciomiesięczny czas do namysłu. Lecz zaledwie trzy dni upłynęło, gdy z rana około piątej godziny, skoro zakonnice ze snu powstały, wszedł do celi przełożonej i zwoławszy wszystkie zakonnice, począł nauczać, że podobnie jak on przekonał się, że dotąd był w błędach i przeszedł do starodawnego kościoła, trzeba i bazyliankom również postapić i wyrzec się swojej wiary. Gdy zaś wszystkie jednozgodnie oświadczyły stałość w wierze i wierność Katolickiemu Kościołowi, Siemaszko rzucił na nie przeklęstwo i kazał natychmiast wszystkim wyjść z klasztoru. Już straż wojskowa była gotowa i rozkaz bez zwłoki wykonano, nie dozwalając nawet poprawić odzienia lub wziąść cokolwiek na drogę,

11 błahoczestliwyj (ros.) - bluźnierczy.

12 Arcychirej - w Kościele prawosławnym tytuł najwyższego duchowieństwa, odpowiadajacy arcybiskupowi w Kościele katolickim. 
tylko jak stały w samym ubiorze, ustapić z klasztoru musiały. Przy furcie jeszcze przemówił do nich Siemaszko, lecz żadna w wierze się nie zachwiała. Prosiły tylko o pozwolenie wnijścia raz jeszcze do kościoła i to im dozwolono. Ostatni to raz więc miały złożyć modły w tej świątyni, gdyż życie swoje poświęcić służbie Bożej ślubowały, i gdzie od lat wielu codziennie przywykły zgromadzać się na chwałę Boga, a dziś na zawsze to miejsce opuścić miały. Jedna $z$ zakonnic, Onufria Laudańska, 60 lat wieku mająca, nie zniosła tak srogiego losu i na modlitwie zakończyła życie.

Pozostałym trzydziestu czterem zakonnicom, po wyjściu z kościoła włożono łańcuchy na ręce, i po dwie na razem skuto, pod strażą jednej kompanii żołnierzy wyprowadzono w drogę piechotą. Pierwsze dwa dni po 6 mil $^{13}$ szły; odpoczywając raz na południe, na noc zaś po wsiach, po 4 lub $6 \mathrm{w}$ jednej chacie zamykano, nie dając na ziemi żadnego posłania. Na żywność przeznaczano każdej po 5 kopiejek, czyli 3 grosze polskie dziennie, oprócz tego zaś żadnego zasiłku nie miały. Gdy lud po drodze zbliżyć się usiłował, zaraz kolbami przez żołnierzy był odpychany. Po sześciu dniach podróży stanęły w Witebsku, gdzie je oddano do klasztoru czernic ${ }^{14}$ ruskich. Są to po większej części wdowy poległych w wojnie lub zmarłych Kozaków, od czarnego ubioru zakonnego czernicami zwane. Przybywszy tam, bazylianki mińskie znalazły czternaście miejscowych sióstr zakonu swego na równy los skazanych. Przeznaczono je wszystkie na usługę czernicom, których liczba w Witebsku kilkadziesiąt wynosiła. Dano im mieszkanie w dymnej izbie czeladnej, na trzy osoby wiązkę słomy na posłanie, i tak nędzne pożywienie, iż ubogie żebraczki przez litość chleb im przynosiły. Wszelkie posługi w domu, w kuchni, w ogrodzie i na poddaszu odbywać musiały zakonnice, jak oto i nosić drwa, palić w piecach, zamiatać w izbach, myć naczynia kuchenne, czyścić dziedziniec, śnieg uprzątać itp. Do najprzykrzejszych zatrudnień liczyły oczyszczanie botów dziegciem czernicom. Ubiór cały czernic jest zupełnie ten sam jak popów monachów ${ }^{15}$; podobne noszą szaty szerokie pasem spięte, na głowie kołpaki $z$ długim $z$ tyłu wiszącym ogonem, spod którego włosy rozpuszczone na ramiona spadają. $\mathrm{W}$ botach zawsze chodzą. Stosowne do tych zatrudnień było obchodzenie się z bazyliankami; jednej z nich, Klarze Żółkiewskiej, czernica głownią oko wyłupiła, wskutek czego umarła. Inna, nazwiskiem, Gertruda Brząsnicka, niosąc drwa $z$ góry, spadła i na śmierć drzewem przywałoną została; dwie z głodu i nędzy wpadłszy w chorobę, umarły. Odwiedzał ich Siemaszko w klasztorze witebskim i namawiał do odstępstwa od wiary, a gdy widział prożne namowy, wołał na zakonnice: i wyście same sobie winne i warte tego, Bóg to was karze.

Dwa lata upłynęły pobytu w Witebsku, podczas tego, gdy się habity zdarły, dano im po dwie koszule $z$ worowego płótna i po dwie spodnice, na głowę zaś częścią swój ubiór miały lub łokieć płótna na ukos przecięty używały na pokrycia.

Po dwóch latach przeprowadzono 30 mińskich zakonnic, a 13 witebskich na nową siedzibe. Szły jak dawniej piechota $z$ Witebska do Połocka. Trzy wiorsty ${ }^{16}$ od Połocka leży nad Dźwiną miejsce $\mathrm{Spa} \mathrm{se} \mathrm{m}^{17}$ zwane. Jest to siedlisko biskupa,

Mila - miara długości dziś już w Polsce nie używana, od 1819 r. równała się 8534,31 m.

Czernica - dawniej mniszka obrządków prawosławnego bądź greckiego.

Pop monach - ksiądz zakonny w Kościołach prawosławnym lub greckokatolickim.

Wiorsta - dawna rosyjska miara długości. Po roku 1835 równa była 1066,79 m.

Spas - mowa o Monasterze Przemienienia Pańskiego i św. Eufrozyny Połockiej. Wybudowany w ro- 
czyli archireja, złożone z mieszkania jego, cerkwi i klasztoru czernic. Archirejem był tu Łużyński ${ }^{18}$, dawniej biskup połocki katolicki, a teraz Greckiego Kościoła. Tu przypędzone zakonnice [---] wsparcia od mieszkańców okolicznych postanowiono na inne miejsce je przeprowadzić. W guberni mińskiej ${ }^{19}$, w powiecie wilejskim, 22 mile od Wilna, leży miasteczko M i a d z i o ł $\mathrm{y}^{20}$, na przesmyku pomiędzy dwoma jeziorami zabudowane. Dawniej było własnością Hrymnickich ${ }^{21}$, dziś rządową. Stał tu niegdyś klasztor i kościół karmelitów ś[w]. Justyna, wsławiony cudami i licznie odwiedzany na odpusty, do których z dalekich stron odprawiano pielgrzymki, przez co miasteczko było zamożne. Dziś opustoszałe, przez Żydów tylko zamieszkałe, kościół na cerkiew zamieniony, a w klasztorze osiadły czernice. Do tego miejsca przeprowadzono bazylianki na mieszkanie dalsze, a za nimi przybył tu także protopop ${ }^{22}$ Michajłowicz ${ }^{23}$. Osadzono je w warsztacie jednym w klasztorze i użyto do zwykłych robót i posług. Między innymi rozbierały gruzy dawne przy klasztorze i z dobytego materiału wybudowały oficynę dla Michajłowicza.

Położenie miejsca nad jeziorami naprowadziło na myśl protopopowi nowy środek do okrucieństwa nad zakonnicami. Rozdzielono je na cztery gromady i zaprowadzono w różne miejsca nad jezioro. Popi i dziaki ${ }^{24}$, chodząc od jednych do drugich, namawiali do odstępstwa od wiary, wołając do nich: Oto tamte już przeszły do starowierstwa, przejdźcież i wy za jej przykładem. Gdy zaś nie dały się złudzić temu pokuszeniami i wszystkie okazały stałość niewzruszona, przystapiono do pławienia ich w jeziorze. W tym celu obleczono je w koszule w kształcie worów zrobione i zadzierzgnięto powrozy pętlą na szyję. Drugi koniec powrozów trzymali dziaki na

ku 1128 z inspiracji świętej prawosławnej Eufrozyny. W roku 1582 Stefan Batory przekazał zabudowania monasteru zakonowi jezuitów. Następnie przez krótki czas - po zdobyciu Połocka przez cara Aleksego I (w 1654 roku) monaster znalazł się ponownie pod jurysdykcją prawosławną, jednak w 1667 roku, na mocy pokoju w Andruszowie, po raz kolejny został zasiedlony przez jezuitów. W latach 1820-1832 obiektem administrował zakon pijarów. W roku 1832 nastapiła kasata zakonu i w roku 1840 znalazł się on znów pod jurysdykcją prawosławną. Od nazwy rusińskiej „spaso-ewfrosinneskij monastyr" wśród okolicznej ludności zakon funkcjonował pod nazwą Spas.

18 Chodzi prawdopodobnie o Bazylego Łużyńskiego (ur. ok. 1788 lub 1791 w Starej Rudni, zm. 26 I 1879 w Petersburgu) - biskupa greckokatolickiego, następnie prawosławnego. Jednego $\mathrm{z}$ organizatorów synodu połockiego, na którym doszło do włączenia struktur unickich na ziemiach litewskich i białoruskich do Rosyjskiego Kościoła Prawosławnego.

19 Jedna z guberni Imperium Rosyjskiego utworzona na ziemiach zabranych I Rzeczypospolitej po drugim rozbiorze Polski w 1793 roku. Istniała do 1917 roku.

20 Obecnie miasto to nazywa się Miadzioł, znajduje się na terenie Białorusi. Miadziolski kompleks karmelitów zbudowany został w 1754 roku w stylu rokokowym - ufundowany przez Antoniego Koszyca, starostę zarzeckiego. Erygowany pod imieniem Matki Bożej Szkaplerznej. Zamknięty w 1832 roku i przeznaczony na klasztor bazylianek. W roku 1866 zamieniony na cerkiew prawosławną. Kompleks klasztorny najbardziej znany był dzięki oryginalnej kalwarii, na którą składało się 21 kaplic i 8 bram położonych w pobliżu kościoła i rynku miasteczka.

21 Nie udało się ustalić informacji na temat tego rodu.

22 Protopop - dawne określenie kapłana prawosławnego wyższego stopnia, który trzymał pieczę nad kilkoma parafiami. Odpowiednik katolickiego dziekana.

23 Chodzi o ks. I gnac e go Michalewicza (taka wersja nazwiska w wersji drukowanej), zwanego tu Michajłowiczem, bazylianina, byłego spowiednika bazylianek w mińskim klasztorze, piastującego funkcje protopopa.

24 Dziak (diak) - w Kościołach prawosławnym i greckokatolickim kantor prowadzacy śpiewy, obeznany w obrządku i liturgii. 
czółnach płynący i ciaggnęli za sobą zakonnice do wody, tak głęboko, że aż po gębę się zanurzały, grożąc im zatopieniem, jeżeli nie przystapią do błahoczestliwej religii. Michajłowicz stał nad brzegiem jeziora i wołał: topić jak szczenięta! Wyprowadzone nareszcie $z$ wody, jak były zmaczane, pędzono do robót, nie dozwalając im do osuszenia się czasu ani sposobności. Pławienie to powtarzano trzy razy wobec ludu zgromadzonego nad jeziorem, przy czym trzy zakonnice utonęły. Tych ciała pogrzebione były nad brzegiem jeziora, gdy zaś obywatel jeden $\mathrm{z}$ pobliskiego miejsca następnej nocy chciał je odgrzebać, dla pochowania w stosowniejszym miejscu, nie znalazł już tych ciał w grobach. Co się z nimi stało, nie wiadomo. Zwyczajem jest w Rosyi podobne zajęcia tajemnica pokrywać i ślad ich w pamięci zacierać.

Asesor klucza miadzolskiego (urzędnik sprawujący władzę policyjną) Zaborowski, za to że zapytany będąc o pławieniu zakonnic, listownie potwierdził prawdę tego zdarzenia, został schwytany i w więzieniu życie zakończył. Wańkowicz ${ }^{25}$, były marszałek guberski miński, za samo wspomnienie w towarzystwie o tych bezprawiach wywieziony został na Sybir.

Protopop Michajłowicz doczekał się w Miadziołach godnego siebie zgonu. Oddawał się często pijaństwu i razu jednego w tym stanie będąc wśród dnia wpadł w kałużę i ugrzął w błocie, tak głęboko, iż śmierć znalazł. Szczęściem, że dzienne światło okazywało jawność czynu, starsza czernica bowiem, nazwiskiem Humenia, ostrzegała, że jeśliby ten wypadek zdarzył się w nocy, wszystkie zakonnice zostałyby pociągnięte do śledztwa i nowych kaźni.

Po dwuletnim pobycie w Miadziołach sied[e]m zakonnic potrafiło ujść baczności straży podczas hulatyki sprawionej na przyjazd Siemaszki i ratowały się ucieczka. Podobnaż okoliczność dała czterem innym sposobność do wymknięcia się spod straży. W miesiącu marcu roku bieżącego] na imieniny protopopa, popi, dziaki i czernice, za nimi zaś straż cała spoili się gorzałka, z czego korzystając przełożona bazylianka Mieczysławska w towarzystwie Konarskiej, Pomarnackiej i jeszcze jednej siostry uciekły z klasztoru. Nie znając wcale okolicy i nie wiedząc, w którą udały się stronę, uszły pierwszego dnia 9 mil, drugiego dnia 8 mil czyli razem przez dwa dni 17 mil, trzymając się, ile możności, lasów i w lesie odbywały noclegi. Pierwsze trzy dni szły bez żadnego pokarmu, oprócz wody, dopiero czwartego dnia podróży ośmieliły się nocować w chlewie pewnego owczarza i żądały od niego chleba. Potem rozdzieliły się w dalszej drodze, obrawszy sobie Kroże ${ }^{26}$ na Żmudzi za miejsce zebrania się, lecz opowiadająca to przełożona sama jedna do końca odbywała podróż i przez Żmudź dostała się przez pruska granicę. Przez jakie miasta przechodziła $z$ Miadzioł do Kroża, rozumie jak w pierwszych podróżach, kędy by przebywała $z$ Mińska do Witebska i Połocka, jakich pomocy doznawała i ułatwień podczas ucieczki z Miadzioł aż do Żmudzi, tego wszystkiego częścią nie pamięta, częścią zataić czuła się obowiązaną ${ }^{27}$.

Być może, mowa o Stanisławi e Wańkowiczu, który w latach 1802-1806 był marszałkiem gubernialnym Mińska.

26 Obecnie miasteczko litewskie, położone w okręgu szawelskim.

27 Warto nadmienić, że początkowe partie tekstu łudząco przypominają treść pierwszego artykułu poświęconego świadectwu - wówczas jeszcze Julii - Mieczysławskiej, opublikowanego na łamach polskiej prasy. Relacje fałszywej ksieni podała „Gazeta Wielkiego Księstwa Poznańskiego” (1845, 
Manuskrypt kórnicki nie zawiera partii tekstu dotyczącej pobytu sióstr w Połocku, poprzedzającego przybycie do Miadzioł. Brakującą treść można jednak zrekonstruować na podstawie wspomnianej już relacji, Les Religieuses basiliennes de Minsk, umieszczonej na łamach „L’Ami de la religion et du Roi”. Materiał zawarty w cytowanym rękopisie kórnickim jest prawie tożsamy z francuską publikacją, różnią się one tylko dwoma elementami: datą wprowadzenia ukazu (być może, pomyłka ta była błędem druku) oraz danymi personalnymi jednej ze zmarłych sióstr (francuskojęzyczna odmiana podaje Rozalię Zabłocką, a kórnicka Onufrię Laudańska). Relacja w jezzyku francuskim, Les Religieuses basiliennes de Minsk, została poprzedzona wstępem, informującym czytelnika o tym, że jej podstawę stanowi oficjalny dokument - protokół sądu metropolitalnego w Poznaniu. Treść dokumentu nie pokrywa się wszakże z zeznaniem złożonym 14 VIII 1845 w obecności księży Thinela i Urbanowicza.

W publikacji na łamach „L'Ami de la religion et du Roi” pojawia się imię „Julia”, które jest znaczące również w tytule rękopisu kórnickiego. Nie zostanie ono natomiast użyte w zeznaniach udostępnionych przez prasę francuską po posłuchaniu, które dał fałszywej zakonnicy papież Grzegorz XVI między 6 XI a 6 XII 1845. Żywotność dotycząca posługiwania się formuła „Julia, z zakonu Makryna Mieczysławska” (czy też „Julia, w zakonie Makryna Mieczysławska”) była niezwykle krótka. Można tu podać dokładną datację, która wiąże się z dwoma publikacjami w polskiej prasie (przywołane już wzmianki: na łamach „Gazety Kościelnej” - Klasztor bazylianek w Mińsku, oraz 2-częściowe Opowiadanie Julii Mieczysławskiej, w „Gazecie Wielkiego Księstwa Poznańskiego”28) i z wymieniona relacją Les Religieuses basiliennes de Minsk. Warto również dodać, że w tomie 3 Historii Zgromadzenia Zmartwychwstania Pańskiego autorstwa Pawła Smolikowskiego imię „Julia” pojawia się w przywołanych wspomnieniach Mieczysławskiej z dzieciństwa, w których mówiła o sobie, używając deminutywu „Julka”29. Fakt ten może stanowić argument przeciwko hipotezie ks. Urbana (podjętej przez Jacka Dehnela w powieści Matka Makryna ${ }^{30}$ ), jakoby za Mieczysławska podawała się Irena Wińczowa ${ }^{31}$. Nieścisła jest również informacja na temat wieku fałszywej bazylianki. Tytuł dokumentu wskazuje, iż w chwili spisywania opowieści w sier-

nry 235-236, z 8-9 X) jako Opowiadanie Julii Mieczysławskiej. Przełożonej zakonu bazylianek $w$ Mińsku. Artykuł ten przedstawiony był jako przedruk z „Kölnische Zeitung” (1845, nr z 30 IX), przywołany przez ks. Urbana. To drugie wspomnienie o Mieczysławkiej w prasie poznańskiej pojawiło się niemalże dwa miesiące po przybyciu ksieni do Poznania i miesiąc po przyjeździe do Paryża. Wcześniejszy artykuł - Klasztor bazylianek $w$ Mińsku, streszczający historię prześladowanych bazylianek, opublikowany był w „Gazecie Kościelnej” (1845, nr 40, z 6 X, s. 311).

Redaktorem naczelnym dziennika był wówczas dr Jan Rymarkiewicz.

29 P. Smolikows ki, Historia Zgromadzenia Zmartwychwstania Pańskiego. T. 3. Kraków 1895, s. 17.

30 P. De hn el, Matka Makryna. Warszawa 2014.

31 Można zauważyć, iż hipoteza ks. U r b a n a (Makryna Mieczysławska w świetle prawdy, s. 117-132) oparta jest na jednej rozmowie odbytej z siostrą zakonną - Katarzyną Mariawitką, dawną opiekunką konwertytów pochodzenia żydowskiego. Nie istnieją wszakże niezbite dowody na poparcie koncepcji, że kobieta podająca się za Makrynę Mieczysławską i Irena Wińczowa to ta sama osoba. 
pniu 1845 ksieni liczyła lat 60. Tego samego roku na łamach „Journal des villes et des campagnes" podawano, iż wiek Mieczysławskiej to 64 lata ${ }^{32}$.

Pewne wątpliwości budzić może data roczna rozpoczęcia prześladowań z rąk Siemaszki. Podług manuskryptu miał to być rok 1837, natomiast w Opowiadaniu Makryny Mieczysławskiej... widnieje rok 1838 (O 1). Ponadto z dokumentu kórnickiego dowiadujemy się, że biskup-apostata dał zakonnicom pięć miesięcy na skłonienie się ku zmianie wiary, wersja zaś drukowana w Paryżu mówi o trzech. Różnica zachodzi również w przypadku personaliów i wieku pierwszej śmiertelnej ofiary prześladowań Siemaszki. Zgodnie z manuskryptem była to Onufria Laudańska, „60 lat wieku mająca”, w wersji drukowanej utrzymywano, że była to „57 lat mająca, 30 lat już zakonnica, nazywała się Rozalia Lauszecka” (O 6). W Opowiadaniu Makryny Mieczysławskiej podano także, iż 60 sierot lamentowało na widok sióstr wyganianych z zakonu, ponadto przedstawiono scenę, w której ksieni, niczym Chrystus, niesie krzyż, oparłszy go o lewe ramię i prawy bok (O 6-7). Różne jest też tempo wędrówki bazylianek. W rękopisie kórnickim zakonnice przez pierwsze dwa dni miały pokonać dystans o długości 6 mil; w wersji drukowanej 8 - pierwszego dnia, następnie „ośm lub dziewięć” (O 7). Nadmieńmy również, że według przekazu kórnickiego siostry przybyły do Witebska po 6 dniach, a w Opowiadaniu Makryny Mieczysławskiej - po 7 (O 8). Publikację wzbogaca także informacja na temat wezwania, pod jakim znajdował się klasztor bazylianek witebskich, czyli Świętej Trójcy (O 8). Ponadto w druku pojawia się nazwisko przełożonej tychże sióstr - Euzebii Tymińskiej, która wraz z 12 miejscowymi zakonnicami była „oddana na posługi” czernicom (O 9) (w rękopisie mowa o 14 bazyliankach).

Z Opowiadania Makryny Mieczysławskiej dowiadujemy się również, iż prześladowcą witebskim sióstr miał być apostata - Michalewicz, który rzekomo przyczynił się do śmierci drugiej zakonnicy - Kolumby Górskiej (O 14). W manuskrypcie kórnickim czytamy o ofierze czernic: Klarze Żółkiewskiej, która straciła życie w wyniku wyłupania oka głownią. Dodajmy, że w wersji drukowanej miast Żółkiewskiej widnieje Nepomucena Grotkowska, która zmarła w wyniku uderzenia polanem w głowe przez siostrę Ihumenę (O 15). Druk zaznajamia nas także $z$ nazwiskami sióstr: Zuzanny Rypińskiej i Koletty Sielawianki, które również miały zginać w Witebsku. W rękopisie zaś mowa o trzech (a w tej liczbie - o Gertrudzie Brząśnickiej oraz dwóch bezimiennych siostrach).

Czytelnik nie pozna $z$ lektury manuskryptu losów bazylianek podczas ich przetrzymywania w Połocku. Szczegóły te można jednak streścić za wspomnianym dokumentem $z$ „L'Ami de la religion et du Roi”. Po przybyciu do Spasu zakonnice zostały oddane pod władze swojego byłego spowiednika - Michajłowicza. Siostry prócz prac wewnątrz klasztoru musiały wykonywać roboty budowlane i asystować kamieniarzom podczas wznoszenia pałacu dla Siemaszki. Wtedy życie straciły trzy zakonnice. Arcybiskup, sfrustrowany niezłomnością sióstr, postanowił zastosować nowe kary cielesne w postaci kijów wymierzanych każdej z zakonnic w środy i piątki. Biskup-apostata zadekretował 30 kijów, a Michajłowicz zwiększył ich liczbę o 20 kolejnych. W wyniku tej kary zmarła jedna z sióstr. Wiadomość o tak surowym 
postępowaniu wywołała oburzenie w całym kraju. Stary generał armii rosyjskiej, do którego dotarły wieści o kaźni zakonnic, podczas swojego pobytu w Połocku odwiedził Michajłowicza i orzekł: „powiesze Cię, łotrze. Car powie: starzec postradał zmysły, ale i tak zostaniesz powieszony" ${ }^{33}$. Wydarzenie to wpłynąc miało na Michajłowicza, który zaprzestał wymierzania kijów zakonnicom. Później od nowa je prześladowano: w tym głodzono oraz usiłowano zastraszyć siostry żywym ogniem, poprzez umieszczenie ich w kręgu płonących gałęzi. Następnie czytamy relację, iż w wyniku zbyt często powtarzających się prób pomocy ze strony mieszkańców zakonnice zostały przeniesione gdzie indziej, tj. do Miadzioł. Dalsza część historii pokrywa się $\mathrm{z}$ tą zamieszczoną $\mathrm{w}$ kórnickim rękopisie.

Warto dodać, iż połockim prześladowcą sióstr podług opublikowanego Opowiadania Makryny Mieczysławskiej był Iwan Wierowkin ${ }^{34}$.

Rękopiśmienna wersja historii ksieni bazylianek zawiadamia nas, jakoby mniszki w Miadziołach miały budować oficynę dla Michajłowicza. Tymczasem w Opowiadaniu Makryny Mieczysławskiej mówi się tylko o wznoszeniu pałacu dla biskupa Siemaszki. Obie odmiany tekstu zgodne sa jednak co do liczby sióstr, które straciły życie w trakcie prac murarskich: zarówno druk, jak i manuskrypt podają bowiem liczbę trzy. Różnica zachodzi wszakże w przypadku śmierci apostaty Michajłowicza, mającego - prawdopodobnie w wyniku kary Bożej, za swe przewinienia po pijanemu utopić się w kałuży. Druk wydarzenie to osadza w Witebsku (O 24), według rękopisu zaś śmierć nastąpiła w Miadziołach. Należy odnotować ponadto odmienną liczbę zakonnic rzekomo zbiegłych z miejsca rosyjskiej kaźni. W manuskrypcie kórnickim mowa jest bowiem o 10 siostrach (w tym dwóch mających ujść prześladowaniom w towarzystwie ksieni i jej śladem udać się do Rzymu). W Opowiadaniu Makryny Mieczysławskiej czytamy tylko o trzech zakonnicach, które zbiegły wraz z przełożoną (O 64-65). W wersji drukowanej podano, iż Mieczysławska uciekła z siostrami: Euzebią Wawrzecką, Klotyldą Konarską, Ireną Pomarnacką (O 58), natomiast w rękopisie kórnickim znajdują się wyłącznie nazwiska Konarskiej i Pomarnackiej.

Interesujące dla kolacjonowania innych wersji opowiadających o represjach wprowadzonych wobec bazylianki wydaje się wspomnienie w omawianym tu manuskrypcie miejscowości Kroże $e^{35}$, która - prócz francuskiej publikacji - nie pojawiła się w późniejszych relacjach dotyczących prześladowania sióstr. Miejscowość ta stanowiła ważny punkt w budowaniu narracji martyrologicznej polskiego narodu. To właśnie w gimnazjum w Krożach nauczycielem był Jan Sobolewski - przyjaciel Adama Mickiewicza, o którym pamięć została utrwalona w części III Dziadów. Frapujące wydaje się zakończenie rękopisu. Zaznaczono w nim, iż przełożona Mieczysławska nie udzieliła dokładnych informacji na temat trasy podróży do Poznania, gdyż pewne detale tej historii „zataić czuła się zobowiązaną"36 (w później-

Les Religieuses basiliennes de Minsk, s. 123.

Zgodnie $\mathrm{z}$ treścią zeznań rzymskich duchowny miał chodzić za siostrami z powrozem powiązanym w węzły i bezlitośnie smagać nim zakonnice. „Powróz” to po rosyjsku „wieriewka” - wszystko więc wskazuje na to, iż Iwan Wierowkin jest kolejnym zmyśleniem.

Wzmianka o miejscowości Kroże poprzez odniesienie do Dziadów mogła być próbą uformowania Makryny Mieczysławskiej na kształt romantycznej, narodowej męczennicy.

Fragment ten wykorzystał Dehnel w powieści Matka Makryna. 
szych relacjach niechęć do zdradzania szczegółów tłumaczono na ogół słabą pamięcią zakonnicy).

Zastanawiające się wydaje, dlaczego polski rękopis opowieści Mieczysławskiej przetłumaczonych i opublikowanych we Francji znalazł się w kórnickiej posiadłości rodziny Działyńskich. $Z$ pewną dozą ostrożności można postawić hipotezę, iż właśnie tam był przygotowany. Wszystko wskazuje, że nie bez powodu w 1927 roku ksiądz Majkowski, stwierdził, iż „pobyt Makryny Mieczysławskiej w Poznaniu spowity jest wieloma tajemnicami" ${ }^{37}$. Jan Wszołek zauważył, że poznańska prasa nie odnotowała wizyty rzekomej ksieni na terenie ówczesnej archidiecezji gnieźnieńsko-poznańskiej. Zdaje się, iż autor słownikowego hasła „Makryna Mieczysławska” przekonanie o utrzymywaniu w tajemnicy pobytu bazylianki w Poznaniu $z$,obawy przed władzami rosyjskimi” zaczerpnął z książki Majkowskiego. Co warto podkreślić, sytuacja unitów na Wschodzie była często poruszana na łamach „Gazety Kościelnej” - katolickiego tygodnika, wychodzącego od 1843 roku pod redakcją ks. Jana Jabczyńskiego, kanonika kapituły metropolitalnej poznańskiej ${ }^{38}$. Np. w numerach z 8 i 14 VII 1845 opublikowany został w dwóch częściach Pamiętnik ks. Konstantego Kuźmickiego, zakonu bazylianów na Litwie, jako naocznego świadka, o zniesieniu gwałtownym unii kościoła ruskiego z rzymskim, którego objętość znacznie przekraczała typowy rozmiar artykułów drukowanych w dziale Rozprawy i rzeczy religïne. Tuż po krótkim wstępie dotyczącym okoliczności zerwania unii przez Rosję carską, podpisany „Ksiądz S. z Galicyi” (który - jak można mniemać - najprawdopodobniej dokonał wyboru poszczególnych fragmentów tekstu) przywołał postać apostaty Siemaszki ${ }^{39}$ :

Znalazł się człowiek, który dla pozornych błyskotek, dla okazania przed światem swoich ministerskich zdolności, dla przypodobania się swojemu monarsze, a może dla zaspokojenia własnych chęci, i dla doprowadzenia do skutku zamiarów od dawna już w sercu swojemu uknowanych, z krzywdą kościoła prawowiernego, hańbiący ten prawdziwego katolika przyjął na siebie obowiązek. Tym człowiekiem jest Józef Siemaszko, byłej brzesko-litewskiej diecezji biskup. [...]

Tak więc wilk drapieżny przyodziany niewinnością baranka stanął na czele trzody, którą postanowił w bezdenną zagrzebać przepaśc $\mathrm{c}^{40}$.

W Opowiadaniu Makryny Mieczysławskiej stwierdzono jakoby Siemaszko:

poznawszy prawdę jedyną, która podług niego jest w Wierze tak zwanej Prawosławnej, do przyjęcia tej wiary a odstapienia Kościoła Rzymskiego i reguły Ś. Bazylego, jako Pasterz owieczki swoje z miłością wielką zachęca i wzywa. [O 1]

W tej relacji ksieni bazylianek przywołany został również wątek zamiłowania biskupa Siemaszki do kosztowności. Mieczyławska wyznaje:

Potem policzkując mię okrutnie, wybił ząb jeden, który ja uczuwszy na języku a z ust wyjąwszy,

Maj k ow ski, Listy Matki Makryny, s. 8.

Choćby 1 IX 1845, a więc najprawdopodobniej niekrótko po wyjeździe Mieczysławskiej z Poznania, w „Gazecie Kościelnej”, w rubryce Doniesienia kościelne, opisywano trudną sytuację Kościoła na Wschodzie.

Autor czy też montażysta wzmiankowanego fragmentu pamiętnika podał m.in. także fałszywy życiorys Siemaszki.

[Ks. S. z Galicy i], Pamiętnik ks. Konstantego Kuźmickiego, zakonu bazylianów na Litwie, jako naocznego świadka, o zniesieniu gwałtownym unii kościoła ruskiego z rzymskim. „Gazeta Kościelna” 1845, nr z 8 VII, s. 209-210. 
ofiarowałam Siemaszce, mówiąc: Weź ten ząb na pamiątkę najpiękniejszego czynu twego, wsadź go między ordery przykrywające kamienne serce twoje; a będzie błyszczał bardziej aniżeli drogie kamienie, za które sprzedałeś swą duszę. [O 23]

Co warto podkreślić, autorzy drukujący w „Gazecie Kościelnej” podjęli temat losów Mieczysławskiej dopiero po głośnych publikacjach we wrześniu w prasie paryskiej (np. w „L'Hermine” 30 IX 1845 czy w „L'Ami de religion et du Roi” 20 IX 1845). 6 X 1845 w „Gazecie Kościelnej” w dziale Rozmaitości zanotowano, iż „jedna z tych nieszczęśliwych [bazylianek], licząca przeszło 60 lat życia, a 36 lat pobytu w zakonie, ucieczką się ratowała i udawszy się przez Żmudź, szczęśliwie dostała się za granicę" ${ }^{41}$. Któryś z przypisów do historii prześladowanych sióstr zakonnych zawierał odniesienie do wydrukowanego wcześniej artykułu o represjach wobec bazylianów. W następnym numerze wspominając o zniesieniu unii, zawarto słowa korespondujące z treścią Opowiadania Makryny Mieczysławskiej:

Rząd umie wszędzie stosować się do wyobrażeń ludu, a zawsze na swoję korzyść i zgubę katolicyzmu. Oderwał on $z$ orężem w ręku unitów od kościoła, ale cóż dalej robi? Ponieważ lud prosty w zebranych prowincjach nic wcale o tym oderwaniu nie wie, bo go nikt pod karą Syberu objaśnić nie może, więc odstępcy kapłani noszą dawny swój ubiór księży łacińskich, nie zawsze zapuszczają brody i gdzieniegdzie tylko za szczególną łaską Cesarz pozwala odstępcom zmieniać rewerendę na togę, a po kilku latach zapuścić brodę w nagrodę zasług 42 .

Pisząc o ks. Michalewiczu/Michajłowiczu - bazylianinie, który dokonał konwersji - poczyniono uwagę o zmianie w jego wyglądzie zewnętrznym:

Gdy przyszła była wiadomość o odstępstwie od Wiary trzech Biskupów Unickich, i prześladowaniu rozpoczętym po innych miejscach, on nas utwierdzał w Wierze ze szczególną a prawdziwie ojcowską i apostolską żarliwością. Odłączone od niego, wzdychałyśmy za nim. Aż oto w tydzień po naszym do Witebska przybyciu, zjawia się nam postać jego, ale z brodą przyprawną: otwierają się usta jego, ale ze słowami fałszu i z mową moskiewską [...]. [O 10-11]

W narracji ks. Urbana jako miejsce kluczowe dla zainicjowania popularności Mieczysławskiej wśród polskiej emigracji i międzynarodowej opinii publicznej jawił się Paryż. O stolicy Wielkiego Księstwa Poznańskiego kapłan ten pisał dość zdawkowo. Wspomniał, iż zakonnica nawiedzająca stolicę Francji 10 IX 1845:

Przywiozła ze sobą listy polecające z Poznania, mianowicie od jenerała Chłapowskiego, Jana Koźmiana (później słynnego kapłana) i arcybiskupa Przyłuskiego, w których przedstawiono ją kolonii polskiej w Paryżu jako ofiarę prześladowania religijnego na Litwie ${ }^{43}$.

Bardziej doceniał pobyt ksieni bazylianek w Poznaniu Zbigniew Sudolski, twierdząc, że „Mieczysławska dostarczyła znakomitych i nowych argumentów przeciw zaborcom, była też żywym świadectwem" ${ }^{44}$. Na nieobecną w stanie badań postać zaangażowaną w sprawę „poznańskiego wątku” Mieczysławskiej wskazał Jan Wszołek w 1975 roku, autor jej hasła w Internetowym polskim słowniku biograficznym:

$41 \quad$ Klasztor bazylianek $w$ Mińsku, s. 8.

42 Doniesienia kościelne: Królestwo Polskie. „Gazeta Kościelna” 1845, nr 41, z 13 X, s. 328. Fragment ten jest szczególnie istotny dla treści wydanego jesienią Opowiadania Makryny Mieczysławskiej.

44 Z. Su d ols ki, Między kłamstwem i prawda. W 150-lecie sprawy matki Makryny Mieczysławskiej. „Przegląd Powszechny” 1995, nr 7/8, s. 78. 
Przez Prusy Wschodnie przybyła w sierpniu do Poznania i zatrzymała się w klasztorze szarytek. T. Działyński polecił spisać jej opowiadanie, a kopie przesłał do Hotelu Lambert oraz do Monachium i Londynu. Z rozkazu arcybpa L. Przyłuskiego lekarze dokonali oględzin jej ciała i potwierdzili istnienie śladów opisanych przez nią tortur. Z obawy przed władzami rosyjskimi pobyt M-iej w Poznaniu utrzymywano w tajemnicy ${ }^{45}$.

Wgląd w korespondencję Tytusa Działyńskiego rzuca więcej światła na kwestię jego zaangażowania w sprawe przekazania polskiej emigracji w Paryżu - spisanej w Kórniku (lub w Poznaniu) - historii Mieczysławskiej. Ważnych informacji dostarcza zwłaszcza fragment jego listu adresowanego do żony - Celiny Działyńskiej, przebywajacej wtedy w stolicy Francji:

Pan Kielisiński wiezie Ci dla księcia Adama tu spisany i niewiarogodny opis dziwnych męczarni, jakie wycierpiały [---] bazylianki w Mińsku i [ich] przełożona - arcygodna kobieta, panna Mieczysławska, która jedzie z Paryża do Rzymu. Bardzo Was wszystkich proszę o największe względy dla niej. Jan Kielisiński ustnie Ci resztę opowie ${ }^{46}$.

Działyński przekazał relację dotyczącą kaźni przełożonej mniszek z Mińska przywódcy Hotelu Lambert za pośrednictwem ówczesnego sekretarza Biblioteki Kórnickiej Kajetana Kielisińskiego. Nie dziwi fakt, iż prośbę o „największe względy” dla Mieczysławskiej skierował Działyński bezpośrednio do żony, która rok przed zjawieniem się ksieni bazylianek założyła w Poznaniu Towarzystwo Dobroczynności Dam Polskich (przekształcone w 1853 roku w Towarzystwo Pań Miłosierdzia św. Wincentego à Paulo), działające przy klasztorze szarytek, gdzie przebywała Mieczysławska ${ }^{47}$. Co równie ważne, list ten zdradza, że już w sierpniu $1845 \mathrm{w}$ Poznaniu pojawił się pomysł podróży ksieni z Paryża do Rzymu, czyli że nie stało się to za namową polskich emigrantów w stolicy Francji! Można zatem sformułować domysł, iż plan przedstawienia papieżowi Grzegorzowi XVI historii bazylianek prześladowanych za wiarę narodził się jeszcze podczas pobytu Mieczysławskiej w Poznaniu. Nie bez znaczenia dla tego zamysłu jest fakt, że w Rzymie trwały wtedy prace nad konkordatem między Stolicą Apostolską a Imperium Rosyjskim, które polska emigracja chciała storpedować ${ }^{48}$.

Zaprezentowane w niniejszym artykule materiały odsłaniają nie znane dotychczas relacje łączące dwór kórnicki z Paryżem (rozgłoszenie historii Mieczysławskiej). Pewne jest, że w bibliotece majątku Działyńskiego znajdował się dokument, którego przekład wydrukowano na łamach francuskiej prasy. Fakt ten, jak i szereg innych tu wymienionych ustaleń pozwala postawić tezę, iż Działyński był współtwórca akcji propagandowej, związanej z upowszechnieniem historii Mieczysławskiej. Brak

J. W s z oł e k, Irena Julia Makryna Mieczysławska. Hasło w: Internetowy polski słownik biograficzny. Na stronie: https://www.ipsb.nina.gov.pl/a/biografia/irena-julia-makryna-mieczyslawska (data dostępu: 8 III 2019).

46 T. D ziały ń ski, list do C. Działyńskiej, z sierpnia 1845, s. 314-315. Na stronie: http://www. wbc.poznan.pl/Content/20059/Listy\%20Tytusa.pdf (data dostępu: 8 III 2019).

47 Informacja ta pochodzi $z$ dokumentu opublikowanego przez ks. E. Majk ow ski e go w periodyku cerkwi greckokatolickiej w Polsce „Biblioteka Zapisków Czynów św. Bazylego Wielkiego” w 1928 roku (s. 85).

48 Zob. więcej o relacjach polskiej emigracji z Watykanem: J. Fi eć ko, Rosja Krasińskiego. Rzecz o nieprzejednaniu. Poznań 2005, s. 318-325, 366-382. 
natomiast materiałów wskazujących na próbę zweryfikowania przez Działyńskiego oraz arcybiskupa Przyłuskiego prawdziwości relacji przełożonej mniszek w Mińsku.

Można zatem przypuszczać, iż przedstawiony tu dokument ze zbiorów Biblioteki Kórnickiej stanowił jedną $\mathrm{z}$ najwcześniejszych odmian opowiadania fałszywej bazylianki. Można też sformułować hipotezę, że faktografia zawarta w kolejnych wersjach opowiadan Mieczysławskiej podlegała licznym zmianom. Pozwala to na przypuszczenie, iż podstawowym celem opublikowania wspomnien „bazylianki” była nie tyle prawda, ile aspekt propagandowy oraz zaprezentowanie Mieczysławskiej jako żywego dowodu na męczeństwo za wiarę na terenach zaboru rosyjskiego ${ }^{49}$.

Kształt oraz losy omawianego rękopisu w stopniu ścisłym splatają się z poznańskimi, a szerzej - wielkopolskimi - losami Makryny Mieczysławskiej. Dodatkowe prace i analizy przeprowadzane nad jego treścia, okolicznościami powstania czy autorstwem - mogą przyczynić się do rozwiązania wielu zagadek związanych z historią fałszywej bazylianki. Okazuje się, iż głębsze zrozumienie wątku poznańskiego historii Mieczysławskiej pozwoli nie tylko przypomnieć i uzupełnić epizod pomijany dotąd w badaniach, w tym dotyczacy faktycznego czasu pobytu ksieni w stolicy Wielkiego Księstwa Poznańskiego. Można będzie precyzyjniej przedstawić rolę Tytusa Działyńskiego i jego sekretarza, Kajetana Kielisińskiego, role Dezyderego Chłapowskiego i Jana Koźmiana, zaangażowanie arcybiskupa Leona Przyłuskiego w sprawy bohaterki, jak i jego wcześniejsze kontakty ze zmartwychwstańcami.

\author{
Abstract \\ ALEKSANDRA SIKORSKA-KRYSTEK Adam Mickiewicz University, Poznań \\ ORCID: 0000-0003-3510-6385 \\ JĘDRZEJ KRYSTEK Adam Mickiewicz University, Poznań \\ ORCID: 0000-0001-5690-8948
}

\title{
SOURCES FROM BIBLIOTEKA KÓRNICKA (THE KÓRNIK LIBRARY) TO MAKRYNA MIECZYSŁAWSKA'S HISTORY
}

The paper is a description of an anonymous manuscript, treasured in The Kórnik Library of the Polish Academy of Sciences, the content of the said manuscript refers to the paper published October $16^{\text {th }}$, 1845, of an article Les Religieuses basiliennes de Minsk (The Basilian Monks of Minsk) in the French "L'Ami de religion et du Roi" ("A Friend of Religion and the King") that relates the course of the supposed persecutions of a Basilian abyss, Makryna Mieczysławska, by the apostate bishop Józef Siemaszko. Tracing the circumstances of Mieczysławska's "Poznan case," the authors prove that the manuscript is not the only evidence that links the Kornik manour of the Działyński family with the issue of the alleged abyss of the Minsk Basilians. Additionally, contrasting the manuscript in question with other handwritten and press sources allows the authors to indicate the field of further research in the political confabulation story of Makryna Mieczysławska.

Warto mieć na uwadze również polityczny wymiar opowieści podanej Grzegorzowi XVI. Na ten wymiar składałyby się próby przekreślenia negocjacji między papieżem a Imperium Rosyjskim dotyczące konkordatu. Rozmowy prowadzone w ciszy przyniosły stronie rosyjskiej znaczące korzyści, np. księża łacińscy ze Stolicą Apostolską kontaktować się musieli za pośrednictwem zwierzchników rosyjskich. 